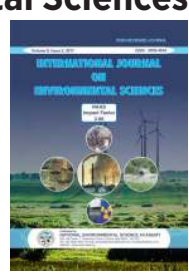

\title{
MILK PRODUCER'S AWARENESS ON ECO-HEALTH PRACTICES IN DAIRY FARMING: A STUDY IN ANDHRA PRADESH
}

\author{
Yerramareddy Roopa* and G.R.K. Sharma \\ Department of Veterinary and Animal Husbandry Extension Education \\ College of Veterinary Science, Tirupati, A.P.
}

\section{Research Article}

Received: 17.09.2021

Accepted: 25.09.2021

Published: 10.10.2021

\begin{abstract}
The present study was conducted in three different regions of Andhra Pradesh state and one district from each reason was selected purposively. 120 milk producers were randomly selected i.e 20 from rural and 20 from urban area of each district comprising 40 from each district with the help of interview schedule. There is a significant $(\mathrm{P}<0.01)$ association between independent variables like age, gender, educational qualification, main occupation, land holding, mass media exposure, extension contact, information seeking behavior, economic orientation, scientific orientation, management orientation with awareness of milk producers on Eco-Health practices. The present study highlights the awareness level of milk producers about Eco-Health practices in dairy farming and the importance of personal, socio-economic, communication and psychological profile for executing the any programmes related to dairy sector for environmental safety, product safety and public health.
\end{abstract}

Keywords: Awareness, Eco-Health practices,Milk producers, Dairy sector, Andhra Pradesh.

\section{INTRODUCTION}

India has been the leading producer of milk and milk products from last few decades. But it was not same for export because of lack of quality. Majority of the Indian dairy sector was occupied by marginal and small farmers who are economically deprived. Most of the milk produced and distributed through informal chain where quality is a big concern. For gaining more profits majority of the farmers were following unethical practices and using misapplications which are not safe for public and environment (Ozturket al. 2019). This may be due to lack of awareness on food safety, animal diseases and impact of dairy sector on environment (Singh, 2019 and Bikokuet al. 2018). Although a great extent of trainings are being carried out in the state departments on dairy production system and a lot of emphases was given on the clean milking production practices but the sad part is that farmer are interested in producing more milk rather than clean milk. One Health collaborative effort involving experts from a wide range of disciplines working for reducing the problems. These networks variously been termed as conservation medicine, one medicine, one health, ecosystem health or agroecosystem health and ecosystem approaches to health, usually shortened to "ecohealth". Eco-Health practices in dairy farm assist milk producers to increase returns by following simple management practices, it helps to utilize natural resources promptly, can reduce the losses due to diseases by incorporating control programmes, increases the health and wellbeing, create coordination with stakeholders involved in dairy sector, gives them confidence about their production, can expects fair price in return according to the quality of product, make them aware of the public health risks associated with adulteration, reduce their reliance on subsidies, and make them feel responsible for environmental pollution from dairy farm. So thestudy was planned to document awareness of urban and rural milk producers from

*Corresponding author: mayaster665@gmail.com,sharmagrk@yahoo.com 
three districts of Andhra Pradesh state towards EcoHealthpractices in dairy sector with respect to environmental aspects, human aspects and product safety.

\section{MATERIALAND METHODS}

The present study was conducted in three regions of Andhra Pradesh state. One district from each region that is Chittoor district from Rayalaseema, Krishna district from Coastal and Vishakhapatnam district from North coastal region were selected. From every district 20 urban and 20 rural milk producers' areas were selected randomly, complaining 120 from three districts. Rural and Urban milk producers were personally interviewed with the help interview schedule. The milk producers were categorized based on the value obtained by dividing the maximum possible score with three since they weregrouped separately into three categories i.e., low, medium and high level of awareness. The range for low, medium and high level of awarenessfor Eco-Health practices with respect to environmental aspects was $<6,6$ to 12 and more than 12respectively, for human aspects it was $<4,4$ to 8 and $>8$ and for product safety it was $<3,3$ to 4 and $>4$ respectively. The awareness was measured on two point continuum i. e. aware (score 1 ) and not aware (score 0). The collected data was tabulated and analysed with the help of SPSS version 23.

\section{RESULTS AND DISCUSSION}

Table 1, 2 and 3 indicate the awareness of milk producers on Eco-Health practise with respect to environmental aspects, human aspects and product safety respectively. It is clear that that the mean

Table 1: Awareness of milk producers about Eco-Health practices with respect to environmental aspects.

\begin{tabular}{|c|c|c|c|c|c|c|c|c|c|}
\hline \multirow[t]{3}{*}{ Visakhapatnam } & \multicolumn{9}{|c|}{ Districts } \\
\hline & \multicolumn{3}{|c|}{ Visakhapatnam } & \multicolumn{3}{|c|}{ Krishna } & \multicolumn{3}{|c|}{ Chittoor } \\
\hline & $\begin{array}{c}\text { Rural } \\
\text { area } \\
(\mathrm{n}=20)\end{array}$ & $\begin{array}{c}\text { Urban } \\
\text { area } \\
(\mathrm{n}=20)\end{array}$ & $\begin{array}{l}\text { Overall } \\
(n=40)\end{array}$ & $\begin{array}{c}\text { Rural } \\
\text { area } \\
(\mathrm{n}=20)\end{array}$ & $\begin{array}{c}\text { Urban } \\
\text { area } \\
(\mathrm{n}=20)\end{array}$ & $\begin{array}{l}\text { Overall } \\
(n=40)\end{array}$ & $\begin{array}{c}\text { Rural } \\
\text { area } \\
(\mathrm{n}=20)\end{array}$ & $\begin{array}{c}\text { Urban } \\
\text { area } \\
(\mathrm{n}=20)\end{array}$ & $\begin{array}{l}\text { Overall } \\
(\mathrm{n}=40)\end{array}$ \\
\hline Biosecurity measures & $3(15)$ & $5(25)$ & $8(20)$ & $8(40)$ & $9(45)$ & $17(42.5)$ & $6(30)$ & $10(50)$ & $16(40)$ \\
\hline Dairy farming impact on climate change & $2(10)$ & $3(15)$ & $5(12.5)$ & $6(30)$ & $8(40)$ & $14(35)$ & $8(40)$ & $10(50)$ & $18(45)$ \\
\hline Impact of climate change on dairy farms & $9(45)$ & $12(60)$ & $21(52.5)$ & $15(75)$ & $15(75)$ & $30(75)$ & $12(60)$ & $16(80)$ & $28(70)$ \\
\hline $\begin{array}{l}\text { Importance of proper disposal of farm waste } \\
\text { for environmental safety }\end{array}$ & $9(45)$ & $14(70)$ & $23(57.5)$ & $12(60)$ & $15(75)$ & $27(67.5)$ & $13(65)$ & $20(100)$ & $33(82.5)$ \\
\hline Greenhouse gases & $6(30)$ & $8(40)$ & $14(35)$ & $10(50)$ & $12(60)$ & $22(55)$ & $11(55)$ & $14(70)$ & $25(62.5)$ \\
\hline $\begin{array}{l}\text { Preventive measure for the reduction of } \\
\text { methane gas emission }\end{array}$ & $0(0)$ & $3(15)$ & $3(7.5)$ & $5(25)$ & $8(40)$ & $13(32.5)$ & $6(30)$ & $9(45)$ & $15(37.5)$ \\
\hline Ill effects of open dung heaps. & $11(55)$ & $15(75)$ & $26(65)$ & $15(75)$ & $16(80)$ & $31(77.5)$ & $14(70)$ & $18(90)$ & $32(80)$ \\
\hline Quarantine period & $6(30)$ & $7(35)$ & $13(32.5)$ & $6(30)$ & $8(40)$ & $14(35)$ & $10(50)$ & $13(65)$ & $23(57.5)$ \\
\hline Water eutrophication & $5(25)$ & $3(15)$ & $8(20)$ & $4(20)$ & $5(25)$ & $9(22.5)$ & $4(20)$ & $7(35)$ & $11(27.5)$ \\
\hline Soil acidification & $1(5)$ & $3(15)$ & $4(10)$ & $3(15)$ & $5(25)$ & $8(20)$ & $4(20)$ & $6(30)$ & $10(25)$ \\
\hline $\begin{array}{l}\text { Environment friendly insecticides that can be } \\
\text { used in dairy farm }\end{array}$ & $7(35)$ & $5(25)$ & $12(30)$ & $6(30)$ & $5(25)$ & $11(27.5)$ & $8(40)$ & $7(35)$ & $15(37.5)$ \\
\hline Importance of cleanliness around farm premises & $20(100)$ & $20(100)$ & $40(100)$ & $20(100)$ & $20(100)$ & $40(100)$ & $20(100)$ & $20(100)$ & $40(100)$ \\
\hline Treatment of dairy effluents & $0(0)$ & $1(5)$ & $1(2.5)$ & $2(10)$ & $4(20)$ & $6(15)$ & $5(25)$ & $7(35)$ & $12(30)$ \\
\hline Environmental impact on human health & $12(60)$ & $15(75)$ & $27(67.5)$ & $15(75)$ & $16(80)$ & $31(77.5)$ & $20(100)$ & $20(100)$ & $40(100)$ \\
\hline $\begin{array}{l}\text { Ill effects on environment due to deplorable } \\
\text { human activities in dairy farm }\end{array}$ & $2(10)$ & $6(30)$ & $8(20)$ & $6(30)$ & $8(40)$ & $14(35)$ & $7(35)$ & $10(50)$ & $17(42.5)$ \\
\hline $\begin{array}{l}\text { Humans-Animals-Environments interface can } \\
\text { also be a source for diseases }\end{array}$ & $6(30)$ & $11(55)$ & $17(42.5)$ & $8(40)$ & $9(45)$ & $17(42.5)$ & $11(55)$ & $15(75)$ & $26(65)$ \\
\hline $\begin{array}{l}\text { Are you aware that this interface impacting the social } \\
\text { and economic well-being of the human population }\end{array}$ & $\begin{array}{c}(30) \\
6\end{array}$ & $11(55)$ & $17(42.5)$ & $8(40)$ & $12(60)$ & $20(50)$ & $11(55)$ & $15(75)$ & $26(65)$ \\
\hline Mean percentage & 30.88 & 41.76 & 36.32 & 43.8 & 51.47 & 47.64 & 50 & 63.8 & 56.91 \\
\hline
\end{tabular}

Figures in parenthesis indicate percentage 
Table 2: Awareness of milk producers about Eco-Health practices with respect to human aspects.

\begin{tabular}{|c|c|c|c|c|c|c|c|c|c|}
\hline \multirow[t]{3}{*}{ Awareness about } & \multicolumn{9}{|c|}{ Districts } \\
\hline & \multicolumn{3}{|c|}{ Visakhapatnam } & \multicolumn{3}{|c|}{ Krishna } & \multicolumn{3}{|c|}{ Chittoor } \\
\hline & $\begin{array}{c}\text { Rural } \\
\text { area } \\
(n=20)\end{array}$ & $\begin{array}{c}\text { Urban } \\
\text { area } \\
(n=20)\end{array}$ & $\begin{array}{l}\text { Overall } \\
(n=40)\end{array}$ & $\begin{array}{c}\text { Rural } \\
\text { area } \\
(\mathrm{n}=20)\end{array}$ & $\begin{array}{c}\text { Urban } \\
\text { area } \\
(\mathrm{n}=20)\end{array}$ & $\begin{array}{l}\text { Overall } \\
(n=40)\end{array}$ & $\begin{array}{c}\text { Rural } \\
\text { area } \\
(n=20)\end{array}$ & $\begin{array}{c}\text { Urban } \\
\text { area } \\
(\mathrm{n}=20)\end{array}$ & $\begin{array}{l}\text { Overall } \\
(\mathrm{n}=40)\end{array}$ \\
\hline Clean milk production & $12(60)$ & $14(70)$ & $26(65)$ & $8(40)$ & $12(60)$ & $20(50)$ & $6(30)$ & $10(50)$ & $16(40)$ \\
\hline $\begin{array}{l}\text { Are you aware why experts recommend } \\
\text { to discard fore-strips of milk }\end{array}$ & $7(35)$ & $12(60)$ & $19(47.5)$ & $5(25)$ & $10(50)$ & $15(37.5)$ & $5(25)$ & $7(35)$ & $12(30)$ \\
\hline Antibiotic withdraw period & $2(10)$ & $4(20)$ & $6(15)$ & $1(5)$ & $3(15)$ & $4(10)$ & $1(5)$ & $1(5)$ & $2(5)$ \\
\hline Diseases that can spread from milk & $5(25)$ & $9(45)$ & $14(35)$ & $4(20)$ & $7(35)$ & $11(27.5)$ & $2(10)$ & $3(15)$ & $5(12.5)$ \\
\hline Awareness about C.M.T kit & $6(30)$ & $9(45)$ & $15(37.5)$ & $4(20)$ & $7(35)$ & $11(27.5)$ & $3(15)$ & $6(30)$ & $9(22.5)$ \\
\hline Awareness about somatic cell count & $1(5)$ & $2(10)$ & $3(7.5)$ & $0(0)$ & $1(5)$ & $1(2.5)$ & $0(0)$ & $1(5)$ & $1(2.5)$ \\
\hline Mean percentage & 27.5 & 41.66 & 34.58 & 18.33 & 33.33 & 25.83 & 14.17 & 23.33 & 26.25 \\
\hline
\end{tabular}

Figures in parenthesis indicate percentage

Table 3: Awareness of milk producers about Eco-Health practices with respect to product safety.

\begin{tabular}{|c|c|c|c|c|c|c|c|c|c|}
\hline \multirow[t]{3}{*}{ Awareness about } & \multicolumn{9}{|c|}{ Districts } \\
\hline & \multicolumn{3}{|c|}{ Visakhapatnam } & \multicolumn{3}{|c|}{ Krishna } & \multicolumn{3}{|c|}{ Chittoor } \\
\hline & $\begin{array}{c}\text { Rural } \\
\text { area } \\
(n=20)\end{array}$ & $\begin{array}{c}\text { Urban } \\
\text { area } \\
(\mathrm{n}=20)\end{array}$ & $\begin{array}{l}\text { Overall } \\
(n=40)\end{array}$ & $\begin{array}{c}\text { Rural } \\
\text { area } \\
(n=20)\end{array}$ & $\begin{array}{c}\text { Urban } \\
\text { area } \\
(\mathbf{n}=20)\end{array}$ & $\begin{array}{l}\text { Overall } \\
(n=40)\end{array}$ & $\begin{array}{c}\text { Rural } \\
\text { area } \\
(n=20)\end{array}$ & $\begin{array}{c}\text { Urban } \\
\text { area } \\
(n=20)\end{array}$ & $\begin{array}{l}\text { Overall } \\
(n=40)\end{array}$ \\
\hline Clean milk production & $12(60)$ & $14(70)$ & $26(65)$ & $8(40)$ & $12(60)$ & $20(50)$ & $6(30)$ & $10(50)$ & $16(40)$ \\
\hline $\begin{array}{l}\text { Are you aware why experts recommend to } \\
\text { discard fore-strips of milk }\end{array}$ & $7(35)$ & $12(60)$ & $19(47.5)$ & $5(25)$ & $10(50)$ & $15(37.5)$ & $5(25)$ & $7(35)$ & $12(30)$ \\
\hline Antibiotic withdraw period & $2(10)$ & $4(20)$ & $6(15)$ & $1(5)$ & $3(15)$ & $4(10)$ & $1(5)$ & $1(5)$ & $2(5)$ \\
\hline Diseases that can spread from milk & $5(25)$ & $9(45)$ & $14(35)$ & $4(20)$ & $7(35)$ & $11(27.5)$ & $2(10)$ & $3(15)$ & $5(12.5)$ \\
\hline Awareness about C.M.T kit & $6(30)$ & $9(45)$ & $15(37.5)$ & $4(20)$ & $7(35)$ & $11(27.5)$ & $3(15)$ & $6(30)$ & $9(22.5)$ \\
\hline Awareness about somatic cell count & $1(5)$ & $2(10)$ & $3(7.5)$ & $0(0)$ & $1(5)$ & $1(2.5)$ & $0(0)$ & $1(5)$ & $1(2.5)$ \\
\hline Mean percentage & 27.5 & 41.66 & 34.58 & 18.33 & 33.33 & 25.83 & 14.17 & 23.33 & 26.25 \\
\hline
\end{tabular}

Figures in parenthesis indicate percentage

percentage of Visakhapatnam, Krishna and Chittoor rural milk producers regarding awareness on EcoHealth practices with respect to environmental aspects, human aspects and product safety was low compared to urban area milk producers. The mean percentages of awareness on Eco-Health practices was below 50 per cent in almost all districts except for Chittoor district regarding environmental aspects and this may be lack of proper exposure to different information sources, unavailability of experts nearby and lack of credit facilities causing disinterest on learning and adoption of scientific technologies which are suitable for present situation. So there is a need to develop interventions that can increas e the awareness level of milk producers through robust educational and training programmers and also it is essential to encourage by providing extra benefits to the dairy farmers who are producing residue free safe milk. The results regarding milk producer's awareness on EcoHealth practices are in agreement with the results of Gupta et al. (2020), Ahuja et al (2019), Singh. (2019), Bikokuet al. (2018) and Aparnaet al. (2013).

Results from Table 4 reveals that from Visakhapatnam district majority of the rural and urban milk producers had low level of awareness on Eco-Health practices with respect to environmental aspects (70\% \&45\%), human aspects (70\% \& 65\%) and Product safety (85\% 
Table 4: Distribution of milk producers according to their awareness score.

\begin{tabular}{|c|c|c|c|c|c|c|c|}
\hline \multirow{3}{*}{$\begin{array}{l}\text { Eco-Health Practices } \\
\text { with respect to }\end{array}$} & \multirow[t]{3}{*}{ Category } & \multicolumn{6}{|c|}{ Districts } \\
\hline & & \multicolumn{2}{|c|}{ Visakhapatnam } & \multicolumn{2}{|c|}{ Krishna } & \multicolumn{2}{|c|}{ Chittoor } \\
\hline & & $\begin{array}{c}\text { Rural } \\
\text { area } \\
(\mathrm{n}=20)\end{array}$ & $\begin{array}{c}\text { Urban } \\
\text { area } \\
(\mathrm{n}=20)\end{array}$ & $\begin{array}{c}\text { Rural } \\
\text { area } \\
(\mathrm{n}=20)\end{array}$ & $\begin{array}{c}\text { Urban } \\
\text { area } \\
(\mathrm{n}=20)\end{array}$ & $\begin{array}{c}\text { Rural } \\
\text { area } \\
(\mathrm{n}=20)\end{array}$ & $\begin{array}{c}\text { Urban } \\
\text { area } \\
(\mathrm{n}=20)\end{array}$ \\
\hline \multirow[t]{3}{*}{ Environmental aspects } & Low $(<6)$ & $14(70)$ & $9(45)$ & $8(40)$ & $4(20)$ & $2(10)$ & $5(25)$ \\
\hline & Medium (6-12) & $5(25)$ & $8(40)$ & $6(30)$ & $7(35)$ & $13(65)$ & $7(35)$ \\
\hline & High $(>12)$ & $1(5)$ & $3(15)$ & $6(30)$ & $9(45)$ & $5(25)$ & $8(40)$ \\
\hline \multirow[t]{3}{*}{ Human aspects } & Low $(<4)$ & $14(70)$ & $13(65)$ & $14(70)$ & $10(50)$ & $15(75)$ & $5(25)$ \\
\hline & Medium (4-8) & $4(20)$ & $4(20)$ & $4(20)$ & $1(15)$ & $0(0)$ & $7(35)$ \\
\hline & High $(>8)$ & $2(10)$ & $3(15)$ & $2(20)$ & $9(45)$ & $5(25)$ & $8(40)$ \\
\hline \multirow[t]{3}{*}{ Product safety } & Low $(<3)$ & $17(85)$ & $14(70)$ & $15(75)$ & $11(55)$ & $15(75)$ & $12(60)$ \\
\hline & Medium (3-4) & $2(10)$ & $5(25)$ & $4(20)$ & $7(35)$ & $2(10)$ & $4(20)$ \\
\hline & High $(>4)$ & $1(5)$ & $1(5)$ & $1(5)$ & $2(10)$ & $3(15)$ & $4(20)$ \\
\hline
\end{tabular}

Figures in parenthesis indicate percentage

Table 5: Association between milk producer's awareness and their independent variables (n=120).

\begin{tabular}{|l|l|c|}
\hline SI. No. & \multicolumn{1}{|c|}{ Independent Variable } & Chi-Square value $\left(\mathbf{X}^{2}\right)$ \\
\hline 1 & Age & $40.504^{* *}$ \\
\hline 2 & Gender & $9.783^{* *}$ \\
\hline 3 & Educational qualification & $77.460^{* *}$ \\
\hline 4 & Family Size & $5.250 \mathrm{NS}$ \\
\hline 5 & Family Type & $7.324^{*}$ \\
\hline 6 & Main Occupation & $9.557^{* *}$ \\
\hline 7 & Land Holding & $20.192^{* *}$ \\
\hline 8 & Herd Size & $6.218^{*}$ \\
\hline 9 & Experience in Dairy Farming & $5.629 \mathrm{NS}$ \\
\hline 10 & Gross Annual Income & $3.214 \mathrm{NS}$ \\
\hline 11 & Dairy Farm Management & $1.319 \mathrm{NS}$ \\
\hline 12 & Mass Media Exposure & $70.220^{* *}$ \\
\hline 13 & Extension Contact & $37.409^{* *}$ \\
\hline 14 & Information Seeking Behavior & $71.052^{* *}$ \\
\hline 15 & Economic Orientation & $55.774^{* *}$ \\
\hline 16 & Scientific Orientation & $52.310^{* *}$ \\
\hline 17 & Management Orientation & $74.061^{* *}$ \\
\hline NS- & & \\
\hline
\end{tabular}

NS-non significant; *-Significant at 5\%; **-Significant at $\mathbf{1 \%}$

\& 70\%). From Krishna district majority of the rural milk producers had low level of awareness on EcoHealth practices with respect to environmental aspects
(40\%), human aspects (70\%) and Product safety (70\%). From rural area majority of milk producers had high level of awareness on Eco-Health practices with 
respect to environmental aspects (45\%) and low level of awareness with respect to human aspects (50\%) and Product safety (55\%). From Chittoor district majority of the rural milk producers had medium level of awareness with respect to environmental aspects (65\%) and low level of awareness with respect to human aspect (75\%) and product safety (75\%). From urban area majority of the milk producers had high level of awareness regarding environmental aspect (40\%) and human aspects (40\%) and low level of awareness on product safety (60\%). The results are similar to the results of Lunner-Kolstrup and Ssali (2016) and Jacob and George (2013). This may be due to the fact that when compared to urban milk producer's majority of the rural milk producers had lower level of education, income, communication profile and psychological profile. Expert from animal husbandry department, state veterinary university and public health officers from medical field may intervene at this juncture and amplify the milk producer's awareness towards Eco-health practices by providing regular trainings, advisory services, field tours to successful farms, exhibitions and providing information in local languages.

It was clear from Table 5 that out of seventeen independent variables, thirteen variables were found to be significantly associated with milk producer's awareness. However, eleven variables namely age, gender, educational qualification, main occupation, land holding, mass media exposure, extension contact, information seeking behavior, economic orientation, scientific orientation, management orientation had highly significant $(\mathrm{P}<0.01)$ association. Similar findings were reported by Ahuja et al (2019) and Ozturket al.(2019).

This may be due to middle and young age milk producers had high level of education, communication and psychological profile compared to old age group. Gender was significantly associated with milk producer's awareness towards Eco-Health practices. Majority of the participants were male who had greater personal, socio-economic, communication and psychological profile compared to females. The significant association with education signals that higher the education levels higher the milk producer's awareness regarding Eco-Health practices. Majority of the milk producer's main occupation was agriculture and animal husbandry which are always interdependent to each other. Land holding was significantly associated with the milk producer's awareness regarding Eco-Health practices. This may be due to the fact that greater land holding provide greater incentive in terms of adoption and applicability of technologies. Mass media exposure was significantly associated $(\mathrm{P}<0.01)$ with the milk producer's awareness regarding Eco-Health practices. The probable reason may be that as the milk producer's exposure towards mass media increases, the awareness on Eco-Health practices also increases.

Extension contact was significantly associated $(\mathrm{P}<0.01)$ with the milk producer's awareness. This may be due to the fact that continuous contact with extension officials leads to knowledge acquisition. Milk producers with higher information seeking behavior had higher awareness regarding Eco-Health practices. This trend may be due to the fact that formal and informal sources will provide more information. There was a significant association between the awareness of milk producers and economic orientation may be due to the fact that farmers who wants to improve the economic status will always try to adopt the technologies and practices and seek information from experts that can improve the farm income. Scientific orientation was significantly associated $(\mathrm{P}<0.01)$ with the milk producer's awareness with respect to Eco-Health practices. The probable reason may be that milk producers having more mass media exposure, extension contact, information seeking behavior and economic orientation guide the milk producer to gain more information and to accept the more new technologies.Management orientation was significantly associated with milk producer's awareness towards Eco-Health practices. This may be due to the fact that farmers with more management orientation which is comprises of planning and production management are more likely to learn the practices that increases the farm revenue.

\section{CONCLUSION}

The findings of the study concluded that the awareness level of milk producers towards Eco-Health practices with respect to Environmental aspects, human aspects and product safety was low in rural areas of Visakhapatnam, Krishna and Chittoor districts compared to urban areas. And even in urban areas it was not up to the mark. This may be due to lack of awareness on Eco-health practices. So there is a need to improve awareness among milk producers by experts from different fields for better understanding 
regarding the concepts of Eco-Health and its importance in dairy sector for reducing environmental pollution, for increasing product safety and for curtail public health risks from dairy sector by considering the socio-economic characters, communication profile and psychological profiles. There is need for great coordination and continuous interaction among stakeholders form dairy sector and experts from line department to conduct different training programmers and to motive the milk producers to avoid unethical practices during milk production which are peril for environment, humans and dairy sector itself.

\section{REFERENCES}

1. Ahuja R., Gautam R. and Sangwan S. S. 2019. Construction of a scale to measure attitude of veterinarians towards animal hygiene. The Pharma Innovation Journal., 8(6): pp 264-269

2. Aparna Saini. S. P. and Hundal J. 2013. Milking management for control of mastitis: Awareness among dairy farmers of Punjab. Veterinary Practitioner., 14(2): pp574-575.

3. Biçoku Y., Zeqiri M. and Gjeçi G. 2018. Awareness about Livestock Standards-the Case of Dairy
Farmers Albania and Kosovo. Albanian Journal of Agricultural Sciences., 17(4): pp187-196.

4. Gupta V. K., Aulakh R. S., Tomar S. S. and Gupta P. 2020. Assessing Milk Safety Related Practices: Opinions, Attitude and Awareness Level Among Dairy Farmers in Malwa Region of Madhya Pradesh (India). Journal of Veterinary \& Marine Sciences., 2(1): pp 30-37.

5. Lunner-Kolstrup C. and Ssali, T. K. 2016. Awareness and need for knowledge of health and safety among dairy farmers interviewed in Uganda. Frontiers in public health., 4(137):pp1-10.

6. Ozturk Y., Celik S., Sahin E., Acik M. N. and Cetinkaya B. 2019. Assessment of Farmers' Knowledge, Attitudes and Practices on Antibiotics and Antimicrobial Resistance. Animals., 9(9): pp 653.

7. Singh J. 2019. A study on the dairy farmer's perception and practices in relation to the concept of eco-health in Punjab. M.V.Sc Thesis, Guru Angad Dev Veterinary and Animal Sciences University, Ludhiana. 